\title{
Research
}

\section{Adaptations of a Yucatec Maya Multiple-Use Ecological Management Strategy to Ecotourism}

\author{
$\underline{\text { Eduardo García-Frapolli }}^{1}$, Víctor M. Toledo ${ }^{1}$, and $\underline{\text { Joan Martinez-Alier }}^{2}$
}

\begin{abstract}
Over the last 40 years, the Yucatan Peninsula has experienced the implementation and promotion of development programs that have economically and ecologically shaped this region of Mexico. Nowadays, tourist development has become the principal catalyst of social, economic, and ecological changes in the region. All these programs, which are based on a specialization rationale, have historically clashed with traditional Yucatec Maya management of natural resources. Using participant observation, informal and semi-structured interviews, and life-history interviews, we carried out an assessment of a Yucatec Maya natural resources management system implemented by three indigenous communities located within a natural protected area. The assessment, intended as an examination of the land-use practices and productive strategies currently implemented by households, was framed within an ecological-economic approach to ecosystems appropriation. To examine the influence of tourism on the multiple-use strategy, we contrasted productive activities among households engaged primarily in ecotourism with those more oriented toward traditional agriculture. Results show that households from these communities allocated an annual average of 586 work days to implement a total of 15 activities in five different land-use units, and that those figures vary significantly in accordance with households' productive strategy (agriculture oriented or service oriented). As the region is quickly becoming an important tourist destination and ecotourism is replacing many traditional activities, we discuss the need for a balance between traditional and alternative economic activities that will allow Yucatec Maya communities to diversify their economic options without compromising existing local management practices.
\end{abstract}

Key Words: ecotourism; human appropriation; México; multiple use; rural metabolism; Yucatec Maya

\section{INTRODUCTION}

The Selva Maya constitutes one of the largest remaining zones of tropical forest in North and Central America, and covers an area including the Yucatan Peninsula, the Lacandon Forest, Belize, Guatemala, and Honduras (Nations et al. 1998, Folan et al. 2000, Faust 2001). The Maya people have inhabited this region for over 3000 years (Lutz et al. 2000). Scholars from a wide range of disciplines have researched myriad aspects of the Maya, including the traditional and contemporary environmental management practices of the Yucatec Maya (see Toledo et al. 2001). Interest in these practices arises from the fact that the Yucatec Maya inhabit a fragile ecological zone, and base their natural resources management strategies on centuries of accumulated experience (Faust 1998, 2001). Nowadays, Yucatec Maya people, with around 1 million speakers, are the main owners and managers of the natural resources of the Yucatan Peninsula (Toledo et al. 2001). Recent economic modernization has introduced new technologies (tractors, hybrid seeds, fertilizers, and herbicides) and their associated cultural frameworks and resource management institutions and practices (monocropping, yield maximization per hectare, loans, credits, privatization of communal lands, protected areas, etc.). The development programs that form part of this innovation have promoted an expansion of arable land use, colonization, increased pasture for cattle ranching, logging, and tourism; these are some of the main causes of deforestation in Mexico (Gómez-Pompa and Kaus 1999).

The uneven implementation and promotion of development programs over the last 40 years on the 
Yucatan Peninsula has economically and ecologically shaped this region of Mexico (Fig. 1). During the first half of the 20th century, the henequen (Agave fourcrodydes Lem.) industry was the region's principal export crop. Practically the entire northwestern part of the Yucatan Peninsula was cleared and planted, at the expense of traditional Yucatec Maya agriculture, and a significant proportion of Mayas were taken from their agricultural fields and forced to work in the henequen haciendas (Eastmond and Robert 2000). The decline of the henequen industry, after the introduction of synthetic fibers in the 1950s, and its devastating impact on the regional economy were partially mitigated by a series of development programs primarily focused on productive specialization (pig and poultry farming, cattle ranching, citrus production, and tourism). The central and some southern parts of the Peninsula are still used for traditional seasonal swidden agricultural (known as milpa) focused on subsistence; little or no government attention has been given to these areas (Peña Chapa et al. 2000, Ewell 1984).

Although pig and poultry farming, cattle ranching, and citrus production have generated productive options for local farmers, tourist development has become the principal catalyst of social, economic, and ecological changes in the region. Cancun is the main tourist center on the Yucatan Peninsula and has become one of the most important tourist destinations in Mexico, attracting over 6 million tourists annually and about one-third of all international tourist revenues in the country (Secretaría de Turismo (SECTUR) 2005). The phenomenon that is Cancun was made possible by the area's beautiful natural setting, the presence of extraordinary nearby archaeological sites, and, most significantly, extensive and detailed planning by public and private agencies and institutions. As a result, the benefits created by the development of Cancun have always been considered in terms of national needs and priorities, meaning that "local people and local resources have been approached as elements to be managed by planners engaged in macroeconomic strategies" (Daltabuit and PiSunyer 1990:9).

Cancun and subsequent development along the nearby Caribbean Coast constitute a success in planned, large-scale tourist development, the benefits of which have not effectively filtered down to society at large. In the early development phases, planners and policy makers were only concerned with transforming local low-yield agriculture into agricultural and ranching industries productive enough to sustain this booming tourist center (Juárez 2002). The fundamental idea behind this approach was to create an interdependent regional economy in which modernization and diversification of local agriculture would provide inexpensive sources of high quality fresh food for tourist service providers (Torres 2003, Klepeis 2003). Government planners and policy makers optimistically believed that the creation of new markets for their products would have potentially positive impacts for smallscale peasant farmers (Torres 2003).

In an analysis of Cancun and the State of Quintana Roo in general, Torres (2003) determined that this potential was only partially realized, and not at all in some cases. In part, the failure of development planners and policy makers can be attributed to two common characteristics of regional development programs: (1) modernization through productive specialization, and (2) lack of integration of indigenous populations (in this case the Maya) into the modernized economy, coupled with a disregard for their ecological knowledge and local natural resource management institutions.

Productive specialization has historically clashed with the Yucatec Maya multiple-use forest management strategy, which is based on the maintenance of available productive activities. This requires diversification in an effort to reduce the risks associated with external socioeconomic and ecological disturbances, guarantee subsistence, and provide partial control over food security (BarreraBassols and Toledo 2005). Therefore, instead of maximizing yields per hectare through monocropping, the multiple-use logic has been to maintain diversity. This traditional management system is open to change (Hostettler 1996); this strategy's approach "is not to experiment with only a few isolated variables, but to incorporate the new within an awareness of system, context, interrelationship, and long-term processes" (Faust 1998:xxiv).

Regional development programs have also excluded the contemporary Yucatec Maya, their culture, knowledge, and local resource management institutions. These institutions are composed of the rules, practices, agreements, and conventions that regulate the implementation of activities and natural resources appropriation (Berkes and Folke 1998). They are the product of an approximately 3000- 
Fig. 1. Productive regions of the Yucatan Peninsula and study site location. (Source: modified from Batllori et al. 2000.)

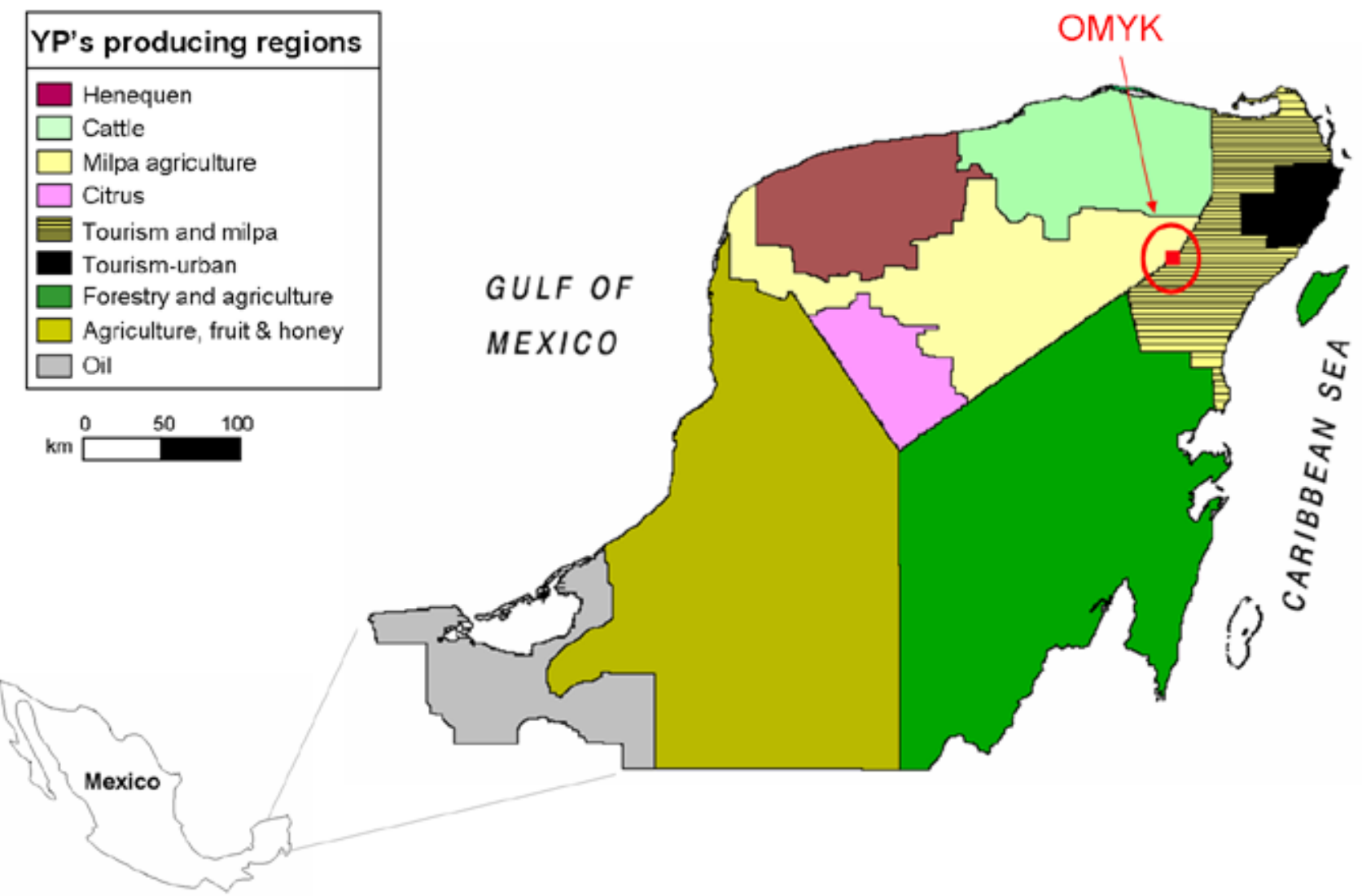

year-long adaptive management process transmitted across generations, and of site-specific agreements regulating natural resources use and management (Faust 1998, Barrera-Bassols and Toledo 2005). Government programs that promote uncritical adoption of "environmentally friendly" activities pose a serious risk to these institutions because their apparent modernity, besides attracting younger villagers, enforces the idea that Yucatec Maya traditional knowledge and institutions are the main causes of their poverty (Faust 1998). This occurs despite the fact that these institutions, which still regulate many communities' resources management
(Gómez-Pompa and Bainbridge 1995), are recognized as vital to maintaining and even increasing regional biodiversity (Faust 2001).

The Yucatec Maya multiple-use natural resources management strategy represents a mode of resilience (Barrera-Bassols and Toledo 2005). It focuses on managing all available (or recognizable) landscape units for production (mature forest, fallow areas, logged forests, homegardens, shifting cultivation and intensive agriculture, and biodiversity embedded in them). As a result, a Yucatec Maya community labels, knows, and uses 
on average between 300 and 500 plant and animal species (Toledo et al. 2008). Because it is multiple use, this strategy implies lower production per landuse unit compared with a specialized-use strategy, but accounts for higher overall production from the aggregate landscape and a dynamic, permanent system based on the benefits of diversity. This strategy, therefore, operates as a risk-reduction mechanism that can potentially absorb both environmental uncertainties and hazards, as well as market fluctuations.

In this paper, we analyze the Yucatec Maya multiple-use strategy and how the implementation of traditional activities adapts to the increasing influence of ecotourism. We do this through a case study of indigenous appropriation of nature by three Yucatec Maya communities located within the Otoch Ma'ax Yetel Kooh (OMYK, "House of Spider Monkeys and Jaguars," in Yucatec Maya) natural protected area (NPA). Using an ecologicaleconomic approach to ecosystems appropriation (Toledo 2008), we show how these communities use and manage their natural resources as a whole. To examine the influence of tourism on the multipleuse strategy, we then contrast productive activities among households engaged primarily in ecotourism, with those oriented more toward traditional agriculture. Our discussion then focuses on the need for a balance between traditional and alternative economic activities that allows these communities to diversify their economic options without compromising existing local management practices.

\section{METHODOLOGY AND CONCEPTUAL FRAMEWORK}

\section{Study Area}

The study was done in the communities of Punta Laguna, Yodzonot, and Campamento Hidalgo, located in the northeastern portion of the Yucatan Peninsula. Although inhabited since well before European contact, the area was unpopulated when Punta Laguna and Yodzonot were established around 1960. These communities were founded by a small group of families that emigrated from their natal town (about $50 \mathrm{~km}$ northeast) in search of forests containing the tree Manilkara zapota (used for extraction of latex, an activity that was abandoned a decade later when it was no longer profitable) and land for milpa agriculture. Campamento Hidalgo was established about 10 years later during construction of the highway from Nuevo Xcan to Coba. Although the communities have been established for less than 50 years, all the community members are of Yucatec Maya ancestry, form part of the larger Yucatec Maya culture, and largely follow its traditional practices.

The dominant vegetation is classified as medium semi-evergreen forest and manifests different successional stages due to milpa agriculture practices and a severe forest fire that occurred after Hurricane Beulah in the late 1960s (Fig. 2). Milpa agriculture is the main productive activity in the area and has created a land-cover mosaic of managed and unmanaged vegetation that ranges from recently abandoned plots to old-growth (>50 years) forest (García-Frapolli et al. 2007). This heterogeneous land cover is common in the humid tropics of Mexico, particularly in areas where cattle ranching is not widespread (Challenger 1998). Faunal biodiversity remains high despite anthropogenic changes in the vegetation (Comisión Nacional de Áreas Naturales Protegidas (CONANP) 2006). Endangered species such as jaguars (Panthera onca), pumas (Puma concolor), black howler monkeys (Alouatta pigra), and black-handed spider monkeys (Ateles geoffroyi) have been reported in the area.

Community-based biodiversity conservation in the area began in 1979 when the National Institute of Anthropology and History (INAH) declared an archeological zone around a Late Classic (AD 7001100) settlement at Punta Laguna, which included a prohibition on productive activities within the zone. Local people began protecting the old-growth forest surrounding the archaeological site and created the Punta Laguna Reserve in response to the increasing arrival of tourists come to watch the sizable spider monkey community living in the area. Punta Laguna was soon renowned among national and international primatologists, and later recognized as one of the five most important potential primate conservation sites in Mexico (Estrada and Coates-Estrada 1988).

A regional non-governmental organization (Pronatura - Peninsula de Yucatan, A.C.) worked closely with locals to have the Reserve declared a federal NPA. This occurred in 2002 when the federal government decreed the 5367-ha Otoch Ma'ax Yetel Kooh Flora and Fauna Protected Area (OMYK, CONANP 2006). The OMYK boundaries form a polygon that encompasses both Yodzonot and Punta Laguna, and 
Fig. 2. Vegetation map of the Otoch Ma'ax Yetel Kooh (OMYK) Flora and Fauna Protected Area in 2003.
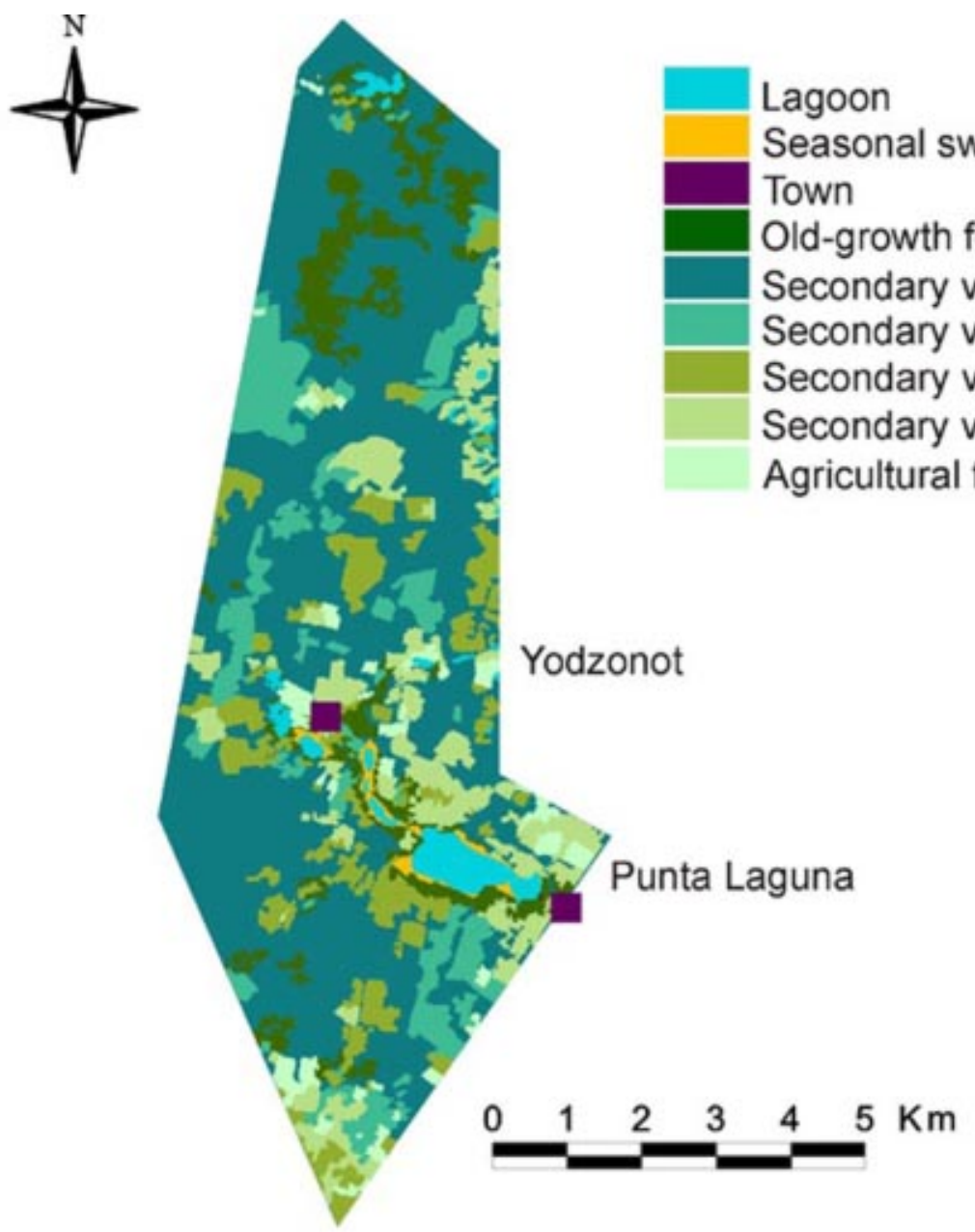

Campamento Hidalgo

leaves Campamento Hidalgo $1.5 \mathrm{~km}$ outside (south). Nevertheless, the people of Campamento Hidalgo use lands within OMYK for some productive activities.

Households in the studied communities produce and sell some goods for market (honey, charcoal, handicrafts, and environmental services such as ecotourism); and buy some of their basic goods from the market (maize, coffee, sugar, medicines, clothing, shoes, tools, cooking utensils, and even cars). For subsistence purposes, they produce maize, beans, squash, chilies, and other fruits and vegetables, and gather common property resources such as subterranean water, firewood, medicinal plants, and wood for house construction. Some household members take seasonal employment in the construction industry along the nearby Caribbean Coast in order to supplement their monetary income. 


\section{Research Methodology}

As actual land use, production, and consumption decision making takes place at the microlevel, the analytical framework was the household unit. Assessment of production, consumption, and the overall natural resources management system was based on this unit, even though each community also functions as a unit and contains institutions that can shape household interactions (Taylor and Adelman 1996). This assessment was intended as an examination of the land-use practices and productive strategies currently implemented by the households in the three communities. Most data were collected between April 2004 and October 2005, although in an earlier visit in 2003, a baseline survey was carried out to identify all productive activities carried out by households. Data collection methods included participant observation, informal and semi-structured interviews, and life-history interviews. Information was gathered with the help of a native Yucatec Maya speaker from outside the OMYK area, who also spoke fluent Spanish.

A total of 63 interviews were done in 42 of the 44 households in the three communities. Only two households from Punta Laguna were unwilling to participate. Of those interviews, 40 focused on productive activities and the remaining 23 on homegarden species variety. Most interviews were done where household members implement their main productive activity (milpa plot, homegarden, old-growth forest, and/or their homes). Respondents in the 40 productive activity interviews were both men and women, whereas in the 23 homegarden interviews all were women, and their homegardens were selected randomly. Once data were collected from each household on labor allocation and yields of economically important activities, seven key informants from the three communities were selected for in-depth interviews. These interviewees were selected based mainly on their broad experience and communication skills, and the interviews were designed to refine concepts, tasks, and measurable units, as well as contrast the household interview data. Finally, life-history interviews were done with two men who founded the community of Punta Laguna.

The research was designed to produce both quantitative and qualitative data. Semi-structured interviews on productive activities were used to allow extensive responses about household implementation of activities (milpa agriculture, charcoal production, beekeeping, wood gathering for cooking and house construction, hunting, ecotourism, scientific research assistance, and handicraft manufacturing), and perceptions about biodiversity conservation and ecotourism activities. Household members described agricultural cycles and seasonal activities, provided total farm size and the land areas devoted to each production unit. Respondents estimated average annual yields (milpa agriculture, charcoal production, beekeeping, fishing, hunting, and harvesting), the number of services they provided (guided tours and research assistance), and total labor allocation to the specific tasks within each activity. Homegarden semistructured interviews were done by walking around in the homegarden with the household member and asking each of them to name and mention the use or purpose of a plant or tree. Thus, all plant and tree species recorded in the study were mentioned at least by one of the householders. Based on study findings and our own observations, we estimated that people in the studied communities dedicated about 8 hours a day to productive activities. Consequently, we adopted a definition of a work day as being equal to 8 hours of labor. Use of this work day introduces some gender bias into the study because it does not reflect the importance of women's activities and their contribution to the household economy. Most women did participate to some extent in the above activities, but most of their work (childcare, cooking, homegardening, laundry, handicraft manufacturing, etc.) demands much more than 8 hours a day.

\section{An Ecological-Economic Approach to Yucatec Maya Ecosystem Appropriation}

One of the key elements to understanding how the Yucatec Maya appropriate nature is the conceptualization of how ecological systems and humans exchange materials or energy, and the physical spaces where these exchanges take place (Toledo 2008). As primary producers facing both natural and social forces, households from the three communities have to be characterized as economic actors constrained within an ecological and social context. This implies that their productive process has to be analyzed in terms of ecological exchanges and economic exchanges. For examining these exchanges, we use a conceptual framework of human appropriation of nature based on the concept of rural metabolism (Toledo 2008). This framework constitutes a powerful tool for analyzing, 
ecologically and economically, the appropriation of natural resources, and it allows us to produce an accurate characterization of rural production.

In their appropriation of nature, the Yucatec Maya have different ways of interacting with their ecosystem (Fig. 3). Each interaction occurs within specific land-use systems-based on a land-use continuum of managed forests, croplands, fallow parcels, old-growth forest, and homegardensorganized spatially and temporally into a patchwork pattern (Barrera-Bassols and Toledo 2005).

Under this generalized scheme, three major environments can be conceptualized in the OMYK area, depending on the activities implemented in them and their effects on the ecosystem. For instance, the Used Environment (UET) was defined as that in which natural resources are obtained through gathering-hunting and fishing activities without provoking substantial changes in landscape structure, dynamics, and architecture. This environment exists in the ecological succession process locally known as hubche'. The Transformed Environment (TET), in contrast, is understood as an artificial ecosystem or agroecosystem (i.e., where domestication of plants and animals occurs) managed to produce as much usable biomass as possible (Fischer-Kowalski and Haberl 1998). Finally, the Conserved Environment (CET) was conceptualized as one in which part of the ecosystem is removed from productive or extractive practices to protect its functioning, species, processes, and services.

For their maintenance and reproduction, Yucatec Maya household units from the three communities are engaged in ecological and economic exchanges across all three Environments. We reduced these exchanges to materials, labor, and commodities flows. We show how households use this strategy to allocate labor to each activity and then obtain material fluxes and services, both for use-value (goods consumed by the household unit) and exchange-value (goods not self-consumed but circulated as commodities outside the household unit). We integrated these three environments through a flux assessment of labor allocation.

\section{RESULTS: THE DIVERSIFIED FOREST MANAGEMENT SYSTEM IN OMYK}

\section{Household Characteristics}

During the fieldwork period (2004-2005), the three studied communities consisted of 44 households (22 in Punta Laguna, eight in Yodzonot, and 14 in Campamento Hidalgo) containing a total of 235 inhabitants (95 in Punta Laguna, 50 in Yodzonot, and 90 in Campamento Hidalgo). Household size ranged from one to 14 members, with an average size of five individuals. All householders were members of the Valladolid ejido with land usufruct rights. Most of the households consisted of indigenous Yucatec Mayas who retained some of their cultural traditions. For instance, the members of almost all the households (82\%) communicated exclusively in Yucatec Maya, whereas the remaining households employed both Yucatec Maya and Spanish. Also, most households still practiced traditional Yucatec Maya religious ceremonies relating to agricultural practices: the rain-calling ceremony was performed by $72 \%$; and the wind deities thanksgiving ceremony by $75 \%$.

Because of geographical location and the specific economic activities implemented in each village, assets and income varied widely between households and villages. Income disparities between households are mainly explained by differential involvement in cash-earning activities such as ecotourism. For instance, households in Yodzonot have not developed any ecotourism activities, but in Punta Laguna, ecotourism activities were monopolized by a few families for many years, generating marked income inequality and increasing social disruption among community members. This tension diminished significantly after all households were included in an ecotourism services cooperative created in 2003. Nevertheless, some households are still excluded to a certain extent due to subtle barriers to full participation (e. g., language). In Campamento Hidalgo, inhabitants have begun an fledgling tourism business based on "traditional and modern Maya culture." Some households here invite tourists into their homes to demonstrate what a traditional Maya home is, as well as showing them wild animals and handicrafts.

Based on householders' responses and on participant observation, we determined the most common productive strategies in the three communities. Because all households managed 
Fig. 3. The Yucatec Maya multiple-use natural resource management approach.

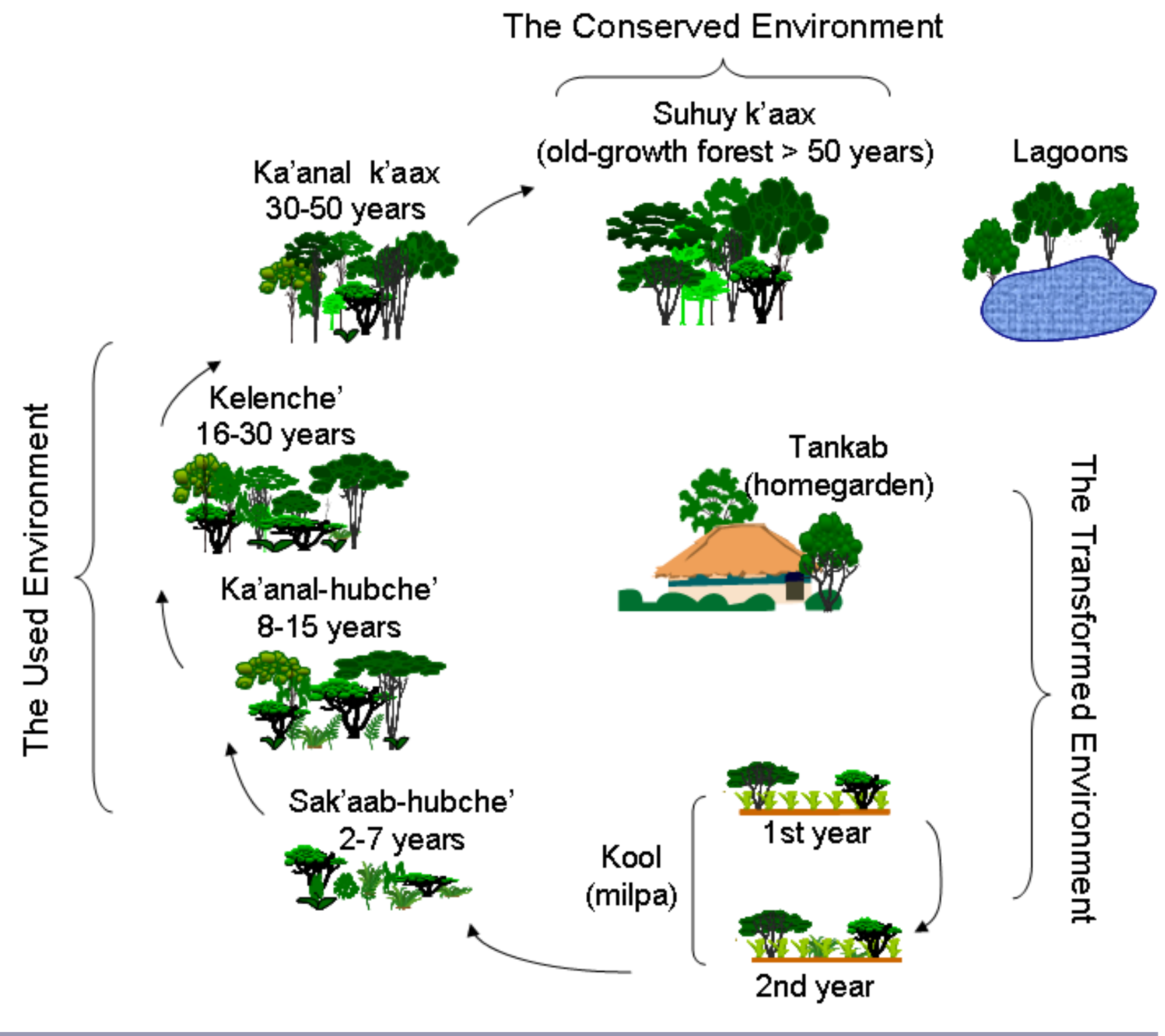


homegardens and implement handicraft manufacturing, these two activities were not explicitly used to define the strategies.

1. Agriculture-oriented: engaged primarily in management of milpa land-use units. Overall, $57 \%$ of OMYK households apply this strategy $(100 \%$ in Yodzonot households, $57 \%$ in Campamento Hidalgo, and $40 \%$ in Punta Laguna).

2. Mixed (agriculture and services): milpa constitutes the main activity, coupled with work as field assistants (i.e., tourist guides or research assistants). Overall, 14\% of OMYK households apply this strategy $(21 \%$ in Campamento Hidalgo, $15 \%$ in Punta Laguna, $0 \%$ in Yodzonot).

3. Service-oriented: main economic activity is service oriented (i.e., tourist guides or research assistants), with minimal work in a small milpa plot or milpa worked by someone else for compensation. Overall, $19 \%$ of OMYK households apply this strategy (40\% in Punta Laguna, $0 \%$ in Yodzonot and Campamento Hidalgo).

4. Other: designates households in which members are either too old to carry out any activity or are entirely dedicated to other economic activities outside their communities (one household in Punta Laguna and three in Campamento Hidalgo).

Household productive strategies differ in the amount of land in milpa agriculture, fallow period, experience in ecotourism activities, and willingness to abandon milpa agriculture (Table 1).

\section{The Multiple-Use Strategy}

In the complete version of the multiple-use strategy, understood as the management of all land-use units and the implementation of all activities in the three Environments (Transformed, Used, and Conserved), households from the three communities managed a total of five land-use units: milpa, homegardens, secondary forest, aquatic systems, and old-growth forest. Following this strategy, OMYK households allocated an annual average of 586 work days (either their own labor or paid to someone outside the household) to implement a total of 15 activities (Table 2). These figures vary significantly in accordance with the productive strategy. Households carrying out an agriculture-oriented strategy implemented 11 economic activities and allocated an annual average of 611 worked days. On the opposite side, households with a service-oriented productive strategy allocated $10 \%$ fewer working days (550) to develop 13 economic activities. Although overall, there is a relative balance between use-value and exchange-value activities (49\% and $51 \%$, respectively), agriculture-oriented households are more dependent on use-value activities (54\%), whereas service-oriented households depend more on cash-earning activities (64\%). Temporary work outside the communities (mainly as construction workers, and less than 1 week per month on average) was included because of its importance $(8.6 \%$ of their average annual worked days).

\section{The Transformed Environment (TET): Agroforestry Production}

Unlike other indigenous communities in the humid tropics of Mexico (e.g., Alcorn 1989, Toledo et al. 1994, Ramírez-Barajas et al. 2001, Toledo et al. 2003), the TET in OMYK is not characterized by management of numerous land-use units. Households in all three communities employ only two land-use units: milpa plots and homegardens. It is clearly a multiple-use strategy, however, given the myriad activities carried out in these two landuse units.

In their milpa plots, households carry out up to five different activities. Some of these require constant year-round labor, such as milpa agriculture and beekeeping, whereas others are less demanding, such as hunting. Still others, such as charcoal production, require occasional very intense labor for short periods of time. This strategy of multiple activities in a household land-use unit diversifies a household's productive options (subsistence and/or market oriented), and maximizes labor time allocation as each activity demands labor in different periods.

As occurs across most of the Yucatan Peninsula, milpa in OMYK is a shifting cultivation system involving continuous rotation through forest fallow, 
Table 1. Households' implementation of milpa agriculture and management of ecotourism. Information is presented by households' productive strategy. A 95\% confidence interval is shown where averages are presented.

\begin{tabular}{|c|c|c|c|c|c|c|c|c|c|c|c|}
\hline \multirow[t]{2}{*}{ Household characterization } & \multicolumn{4}{|c|}{$\begin{array}{c}\text { Productive strategies } \\
\text { implemented by } \\
\text { households from the three } \\
\text { communities and OMYK } \\
\text { as a whole }(\%)\end{array}$} & \multirow[t]{2}{*}{$\begin{array}{l}\text { Did } \\
\text { milpa } \\
\text { in pre- } \\
\text { vious } \\
\text { year }(- \\
\%)\end{array}$} & \multirow[t]{2}{*}{$\begin{array}{l}\text { Average } \\
\text { milpa s- } \\
\text { ize (ha) }\end{array}$} & \multirow[t]{2}{*}{$\begin{array}{c}\text { Average } \\
\text { distance } \\
\text { to milpa } \\
(\mathrm{km})\end{array}$} & \multirow[t]{2}{*}{$\begin{array}{l}\text { Average } \\
\text { fallow } \\
\text { period } \\
(y r)\end{array}$} & \multirow{2}{*}{$\begin{array}{l}\text { Average } \\
\text { years w- } \\
\text { orking in } \\
\text { ecotourism } \\
\text { activities }\end{array}$} & \multirow{2}{*}{$\begin{array}{l}\text { Willing- } \\
\text { ness to } \\
\text { reduce } \\
\text { milpa and } \\
\text { increase } \\
\text { ecotourism } \\
\text { activities } \\
(\%)\end{array}$} & \multirow{2}{*}{$\begin{array}{l}\text { Willingness to } \\
\text { abandon mi- } \\
\text { lpa agriculture } \\
\text { (\%) }\end{array}$} \\
\hline & PL & $\mathrm{Y}$ & $\mathrm{CH}$ & OMYK & & & & & & & \\
\hline Agriculture oriented & 40 & 100 & 57 & 57 & 100 & $\begin{array}{c}4.7 \\
\pm 0.60\end{array}$ & $\begin{array}{l}2.1 \\
\pm 0.41\end{array}$ & $\begin{array}{c}18 \\
\pm 1.79\end{array}$ & $\begin{array}{l}1.3 \\
\pm 0.51\end{array}$ & 100 & 0 \\
\hline $\begin{array}{l}\text { Mixed (agriculture and service } \\
\text { oriented) }\end{array}$ & 15 & 0 & 21 & 14 & 100 & $\begin{array}{l}3.4 \\
\pm 1.30\end{array}$ & $\begin{array}{l}2.3 \\
\pm 1.06\end{array}$ & $\begin{array}{c}16 \\
\pm 5.89\end{array}$ & $\begin{array}{c}4.0 \\
\pm 1.34\end{array}$ & 100 & 50 \\
\hline Service Oriented & 40 & 0 & 0 & 19 & 86 & $\begin{array}{l}2.5 \\
\pm 1.68\end{array}$ & $\begin{array}{c}2.1 \\
\pm 0.69\end{array}$ & $\begin{array}{c}5 \\
\pm 1.67\end{array}$ & $\begin{array}{c}9.6 \\
\pm 3.47\end{array}$ & 100 & 29 \\
\hline Other & 5 & 0 & 21 & 10 & 0 & 0.0 & na & na & 0 & na & na \\
\hline
\end{tabular}

OMYK=Otoch Ma'ax Yetel Kooh NPA; PL=Punta Laguna; Y=Yodzonot; CH=Campamento Hidalgo; na=not applicable.

in which maize is planted in conjunction with other crops (mainly squash, beans, chilies, but also tomatoes, sweet potato, manioc, and some fruits). The milpa system in OMYK involves planting at a fixed site for 1 to 2 years followed by rotation to a new plot, and abandonment of the previous plot to natural vegetation regeneration. The region's rocky, irregular soils prevent mechanized agriculture. During the research period, approximately 150 ha within the NPA (3\% of total area) were under milpa agriculture, which has remained relatively constant over the last 5 years (García-Frapolli et al. 2007).

The average amount of land used at any given time by each household in the NPA is approximately 4 ha and plot distance from the household is about 2 $\mathrm{km}$. However, this belies important differences between households and their productive strategies. First, average milpa plot size and the average amount of labor allocated to this activity decreases from 4.7 ha and 316 annual worked days in agriculture-oriented households, to 3.4 ha and 286 worked days in mixed households to 2.5 ha and 192 worked days in service-oriented households. Second, in service-oriented households, milpa plots are usually cleared on a more recently abandoned milpa plot (5 years on average) rather than clearing one in an advanced stage of regeneration (18 years on average in agriculture-oriented households). Households with members working as field assistants tended to choose new milpa plots based on ease of access and the presence of younger, more easily cleared vegetation. This means that they are shortening the fallow period before reusing milpa plots, which could negatively affect sustainability in the area. García-Frapolli et al. (2007) reported that, in $2003,14 \%$ of new milpas in OMYK were cleared in the 2- to 7-year successional stage, a suboptimum stage due to its relatively low soil nutrient availability.

Task and labor allocation in milpa agriculture is directly linked to implementation of other activities in the milpa land-use unit. For instance, the period of highest labor demands in beekeeping (winter) coincides with that of lowest labor demand in milpa agriculture. Currently, $48 \%$ of OMYK households, especially those who have an agriculture-oriented and mixed productive strategy, engage in beekeeping, with an average of five Apis mellifera colonies. Interviewees stated that many are reluctant to do beekeeping because it involves a high level of 
Table 2. Annual estimated work days allotted to each activity. Numbers are per household, characterized by their productive strategy and based on an 8-hour work day.

\begin{tabular}{|c|c|c|c|c|c|}
\hline \multirow[t]{2}{*}{ Activity } & \multirow[t]{2}{*}{ Agriculture oriented } & \multirow[t]{2}{*}{ Mixed } & \multirow[t]{2}{*}{ Service oriented } & \multicolumn{2}{|c|}{ OMYK } \\
\hline & & & & Total & $\%$ \\
\hline Milpa agriculture & 206 & 151 & 116 & 178 & 30.5 \\
\hline Handicrafts & 108 & 116 & 100 & 107 & 18.3 \\
\hline Homegardening & 84 & 61 & 57 & 74 & 12.7 \\
\hline Charcoal production & 67 & 89 & 0 & 56 & 9.6 \\
\hline Temporary work & 61 & 48 & 20 & 50 & 8.6 \\
\hline Research assistance & 0 & 0 & 135 & 28 & 4.9 \\
\hline Ecotourism* & 11 & 41 & 89 & 27 & 4.6 \\
\hline Firewood & 28 & 28 & 5 & 23 & 4.0 \\
\hline Beekeeping & 18 & 20 & 10 & 17 & 2.9 \\
\hline Sheep ranching & 17 & 0 & 0 & 10 & 1.8 \\
\hline Hunting & 6 & 7 & 9 & 7 & 1.2 \\
\hline Wood for house construction & 5 & 5 & 5 & 5 & 0.9 \\
\hline Fishing & 0 & 0 & 3 & 1 & 0.1 \\
\hline Total & 611 & 567 & 550 & 586 & 100 \\
\hline Use-value activities (\%) & 53.9 & 44.6 & 35.6 & 49.3 & \\
\hline Exchange-value activities (\%) & 46.1 & 55.4 & 64.4 & 50.7 & \\
\hline
\end{tabular}

OMYK=Otoch Ma'ax Yetel Kooh NPA

* Includes entrance-fee collectors, tourist guides, and reserve custodian

underlying risk. The frequent occurrence of hurricanes in the region increases the probability of losing their entire investment, as happened in 2005 after hurricanes Emily and Wilma.

The tourist boom along the Caribbean Coast has made charcoal production very popular among agriculture-oriented and mixed households in OMYK, because the product obtained is sold to restaurants in Tulum and Playa del Carmen. Like beekeeping, charcoal production occurs in the milpa land-use unit and requires synchronization with other milpa activities, especially vegetation cutting and burning. It produces good cash income and takes a relatively short period of time (3 weeks on average) from cutting of vegetation to sale of sacks of charcoal. Finally, households obtain a large amount of their firewood for cooking (79\% of firewood) from the milpa plot, and hunt game species that visit milpa plots.

Homegardens are the second land-use unit managed by OMYK inhabitants in the TET. This agroforestry system is located in the area surrounding homes, 
and contains a highly diverse flora that is a critical complement in household nutrition (Caballero 1992, Toledo et al. 2008). The members of OMYK households recognized the use of a total of 131 species from homegardens. The main uses for these species were as food ( $28 \%$ fruit trees and $20 \%$ edible plants), medicine $(22 \%)$, for religious ceremonies $(13 \%)$, as ornaments (9\%), household utensils and other uses such as toys and forage (8\%). Homegardens are also where domestic animals (mainly pigs and chickens) are raised for use in celebrations. On average, service-oriented households allocated less labor to this land-use unit (57 annual worked days vs. 84 by agriculture-oriented households) because some service-oriented households are related families and shared the same homegarden.

The data for the percentage of households that used this Environment, the activities they carried out there, and the amount of labor allocated to it (Table 3 ) indicate they engaged in a total of six activities: two (beekeeping and charcoal production) for market purposes, and four for subsistence. Usevalue activities accounted for almost $80 \%$ of total labor allocation, $73 \%$ of which was represented by milpa agriculture and homegardening, both vital to partial control of household food security. However, as Table 3 shows, significant differences are found in the relative importance that this Environment has in households' natural resource management strategies.

\section{The Used Environment (UET): Gathering, Hunting, and Fishing}

The OMYK households managed two land-use units (secondary forest and aquatic systems) and implemented five activities (fishing, sheep ranching, gathering of wood for house construction and cooking, and hunting) within the UET. In work days, this Environment accounted for a smaller proportion of the time allocated by households for their overall natural resources appropriation strategy (Table 4). For instance, fishing was only used by two households in Punta Laguna, and sheep ranching, the only market-oriented activity in this Environment, was implemented by three households (one in each community). In terms of gathering (firewood, building materials, game), activities also occur on a small scale: (1) only $21 \%$ of firewood is gathered in this Environment; (2) subsistence hunting is losing importance as a food source, as according to locals, species such as collared peccary (Pecari tajacu) and ocellated turkey (Agriocharis ocellata) have almost disappeared from OMYK; and (3) although wood, vines, palm fronds, and other materials are usually collected from the successional forest, most recently built houses contain some materials purchased in nearby towns.

\section{The Conserved Environment (CET): Non- Extractive Activities}

The CET in OMYK was initially created by an internal decision made by a few Punta Laguna community members who left their portion of the forest surrounding Punta Laguna's lake untouched rather than cultivate it like other community members. Their intent was to protect a significant portion of the old-growth forest ( $>50$ years old) surrounding the community and lakes to protect the spider monkey community, which is the primary tourist attraction. Within this approximately 200-ha conserved environment, locals made an agreement not to carry out productive or extractive activities; only ecotourism and scientific research were allowed. Although the area is currently managed by local inhabitants, the OMYK's status as a NPA places it under administration of the CONANP, meaning all management and use activities follow the guidelines of the management plan (CONANP 2006).

Tourists first began arriving at Punta Laguna in the late 1970s and, since then, ecotourism activities (both direct and supporting) have become vital to some households. For instance, in Punta Laguna, $36 \%$ of households allocated practically all their labor force to this Environment (i.e., serviceoriented households), and an additional $14 \%$ were mixed households combining activities in the Conserved and Transformed Environments.

Over the last 10 years, households have gradually reduced their activities in the Transformed Environment and increased their activity in the Conserved Environment. Although tourist arrivals and consequent earnings have fluctuated over the years (Fig. 4), ecotourism activities have generated significant changes in household productive and resource use strategies. The first of the two primary reasons for this transition is the greater earning power of those involved in ecotourism. For several 
Table 3. Activities and average annual labor allocation by households' productive strategy and OMYK as a whole in the Transformed Environment (TET). Numbers are per household and based on an 8-hour work day.

\begin{tabular}{lcccccc}
\hline \hline & $\mathrm{AO}$ & $\mathrm{M}$ & $\mathrm{SO}$ & \multicolumn{2}{c}{ OMYK } \\
& $\mathrm{N}=24$ & $\mathrm{~N}=6$ & $\mathrm{~N}=8$ & Total & Use-value & Exchange-value \\
\hline Transformed Environment & 400 & 347 & 192 & 347.9 & 274.7 & 73.2 \\
Milpa land-use unit & 316 & 286 & 135 & 273.5 & 200.2 & 73.2 \\
Milpa agriculture & 206 & 151 & 116 & 178.3 & 178.3 & 0.0 \\
Charcoal production & 67 & 89 & 0 & 56.3 & 0.0 & 56.3 \\
Firewood & 22 & 22 & 4 & 18.5 & 18.5 & 0.0 \\
Beekeeping & 18 & 20 & 10 & 17.0 & 0.0 & 17.0 \\
Hunting & 3 & 4 & 5 & 3.4 & 3.4 & 0.0 \\
Homegarden land-use unit & 84 & 61 & 57 & 74.4 & 74.4 & 0.0 \\
Homegardening & 84 & 61 & 57 & 74.4 & 74.4 & 0.0 \\
\hline
\end{tabular}

$\mathrm{AO}=$ Agriculture oriented; $\mathrm{M}=$ Mixed; $\mathrm{SO}=$ Service oriented; OMYK=Otoch Ma'ax Yetel Kooh NPA

years, all income from entrance fees, guiding tours, and handicraft sales was earned by a small number of households, those who initiated the ecotourism business. Their purchasing power has understandably grown substantially and they have been abandoning other productive activities (especially milpa agriculture, see Table 2). For the remaining, mostly agriculture-oriented, households, tourism promises far better income than beekeeping and charcoal production. The second reason is that ecotourism activities are far less labor intensive than those activities implemented in the Transformed Environment.

The number of visits and revenues earned were notable, but the obvious drop in both highlights a strong local dependence on travel agencies to bring in visitors. Most tourists visiting OMYK during the last 10 years were brought by a single travel agency. After the area was officially decreed a protected area, locals anticipated an increase in visits, and the ecotourism services cooperative raised the entrance fee from USD\$0.90 to USD\$1.33. In retaliation, the travel agency stopped bringing tourists to OMYK and most visitors were arriving by their own means. Numbers of visits to OMYK recovered until 2006 when the cooperative signed a new agreement with a major travel agency.

The CET has also attracted another type of visitor. Primatologists researching spider monkey behavior have been coming to OMYK since the mid-1980s. Because of their interest in working in an undisturbed environment, in which spider monkeys can easily be observed, primatologists quickly became allies of the households promoting conservation of the spider monkey habitat. A small number of household members have been working as full-time research assistants on these research projects. Not surprisingly, these same households are those that initially developed and monopolized ecotourism in OMYK. In recent years, Yodzonot household members have found occasional work with other researchers (mainly plant ecologists).

Two types of occupations have been created since the CET was established (Table 5). Jobs directly related to ecotourism are tourist guides and entrance 
Table 4. Activities and average annual labor allocation by households' productive strategy and OMYK as a whole in the Used Environment (UET). Numbers are per household and based on an 8-hour work day.

\begin{tabular}{lcccccc}
\hline \hline & $\mathrm{AO}$ & $\mathrm{M}$ & $\mathrm{SO}$ & \multicolumn{2}{c}{ OMYK } \\
& $\mathrm{N}=24$ & $\mathrm{~N}=6$ & $\mathrm{~N}=8$ & Total & Use-value & Exchange-value \\
\hline Used Environment & 31 & 15 & 17 & 24.6 & 14.2 & 10.4 \\
Secondary forest & 31 & 15 & 14 & 24.0 & 13.6 & 10.4 \\
Sheep ranching & 17 & 0 & 0 & 10.4 & 0.0 & 10.4 \\
Wood house construct. & 5 & 5 & 5 & 5.3 & 5.3 & 0.0 \\
Firewood & 6 & 6 & 1 & 4.9 & 4.9 & 0.0 \\
Hunting & 3 & 4 & 5 & 3.4 & 3.4 & 0.0 \\
Aquatic systems & 0 & 0 & 3 & 0.6 & 0.6 & 0.0 \\
Fishing & 0 & 0 & 3 & 0.6 & 0.6 & 0.0 \\
\hline
\end{tabular}

$\mathrm{AO}=$ Agriculture oriented; $\mathrm{M}=$ Mixed; $\mathrm{SO}=$ Service oriented; OMYK=Otoch Ma'ax Yetel Kooh NPA

fee collectors. Fifteen Punta Laguna community members rotate as tour guides, and all Punta Laguna households are allotted (by rotation) 1 month a year to collect entrance fees. Reserve custodian, research assistant, and handicraft artisan are other CETrelated jobs, but are not directly involved in ecotourism activities.

\section{DISCUSSION}

Since Redfield and Villa Rojas' (1934) contribution to the understanding of Yucatec Mayas ethnography, the Maya people, their culture, region, and mode of resource use have been a continuous subject of research from many different disciplines. In part, this fascination with the Maya can be attributed to the fact that, in a hostile and difficult environment for human development and agriculture, the Mayas have preserved their culture and nature over the long term (Gómez-Pompa 2003). For several decades now, the image of the Mayas as mere swidden farmers has been altered by many findings. Harrison and Turner's book (1978) demonstrated the existence of several intense and complex types of cultivation in the whole Maya region. Gómez-Pompa's extensive research on the Mayas has suggested a complex way of nature appropriation, both in the present and in the past. In this, Mayas have managed a great diversity of forest gardens where they domesticated, semidomisticated, cultivated, or semicultivated many plant and animal species (Gómez-Pompa 1987). As well, BarreraBassols and Toledo (2005) have offered abundant evidence on how Yucatec Maya's management of tropical ecosystems is based on multiple use, which signifies lower production per unit of land used but higher production for the aggregate landscape. This multiple use is a dynamic, flexible, and permanent system based on the benefits of diversity.

Although the Mayas remain a viable and vigorous culture (Faust 2001, Gómez-Pompa 2003, Martínez-Ballesté et al. 2006), they face several challenges in terms of adapting to ecological and socioeconomic changes posed by the way in which the region and most of the world is developing. Over the last couple of decades, tourism has become one of the world's fastest-growing industries, to the point of providing $8 \%$ of global employment and $10 \%$ of the world's GNP (World Travel and Tourism Council (WTTC) 2008). For developing countries like Mexico, and especially the Yucatan 
Fig. 4. Total tourist visits and entrance fee revenues at OMYK from 2002 to 2006.

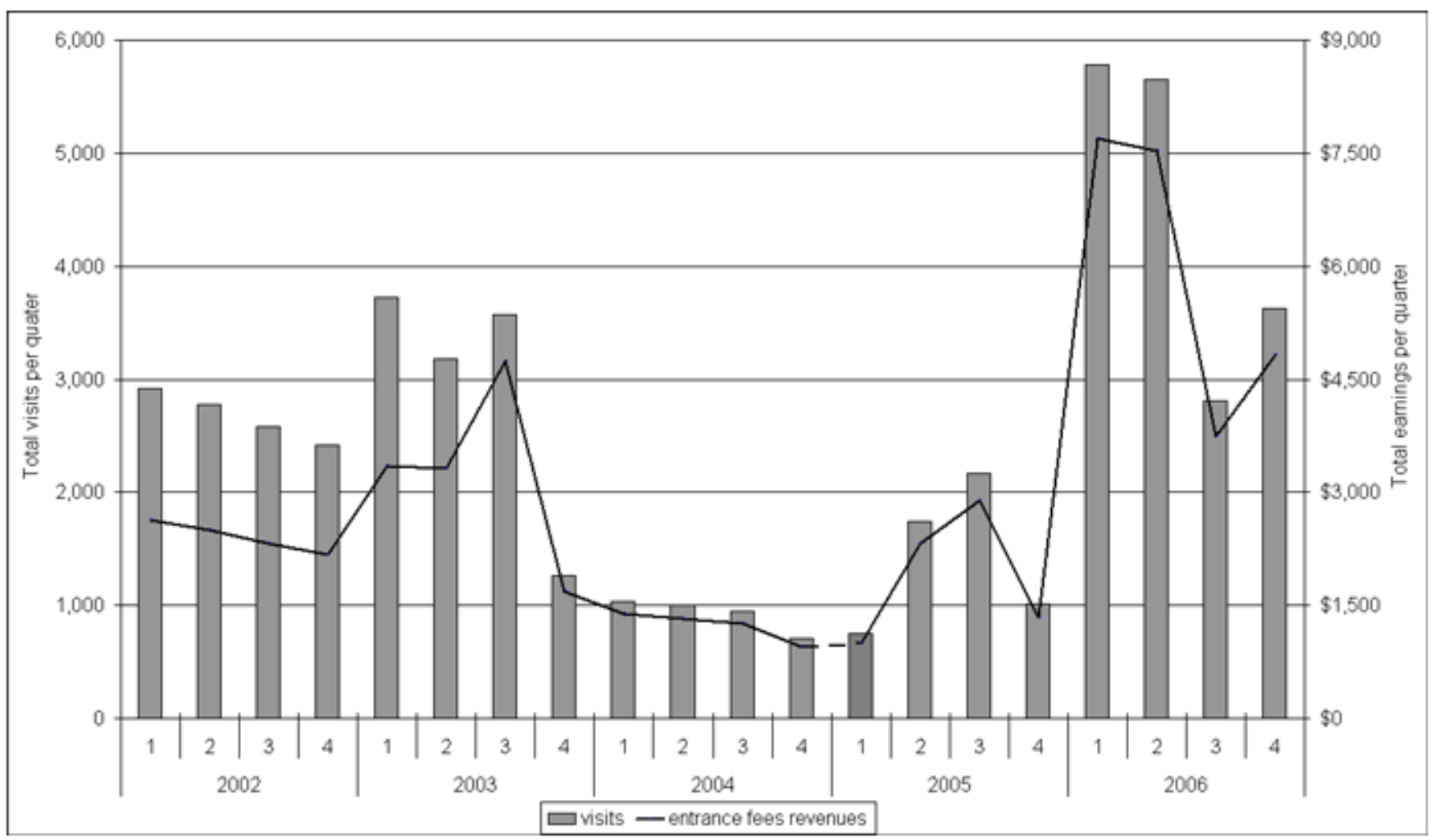

Peninsula with its $120-\mathrm{km}$ strip of coast between Cancun and Tulum, this industry has proved to be a truly important source of foreign exchange inflows, significant employment opportunities, development capital, and economic diversification (Wunder 2000). However, the mass flows of tourists have also created a significant range of problems, which include aspects such as environmental, social, and cultural degradation (Juárez 2002), land rights pressures and migration ( Re Cruz 2003, Torres 2003), land-use changes and abandonment of traditional activities (Martínez-Ballesté et al. 2006, Hostettler 1996), unequal distribution of financial benefits (Daltabuit and Pi-Sunyer 1990), and the promotion of paternalistic attitudes (Faust 2001).

The case study illustrates how communities in this region of Mexico, besides obtaining benefits from tourism in the form of employment and off-farm income opportunities, are encountering increasing pressure from this thriving economic industry. Many of these pressures not only emerged from the usual dynamics of an increasingly demanding economic sector, but also from the way it has been promoted by a centralized development approach (Klepeis 2003). Until recently, most government development programs were focused mainly on increasing agricultural productivity through specialization, with the idea of a primary agriculture center that would supply tourist urban areas within the region (Klepeis 2003). Government development policies involved the imposition of technologies and cropping systems that had never been tested in the region and were targeted at fragmented pieces of Yucatec Maya natural resources management strategy (e.g., in our conceptual framework, this translates into concentrating on the management of a single Environment for livelihood). Yucatec Maya farmers have participated actively in these development programs as beneficiaries and part of a client labor force, but with very limited influence 
Table 5. Activities and average annual labor allocation by households' productive strategy and OMYK as a whole in the Conserved Environment (CET). Numbers are per household and based on an 8-hour work day

\begin{tabular}{lcccccc}
\hline \hline & $\mathrm{AO}$ & $\mathrm{M}$ & $\mathrm{SO}$ & \multicolumn{2}{c}{ OMYK } \\
& $\mathrm{N}=24$ & $\mathrm{~N}=6$ & $\mathrm{~N}=8$ & Total & Use-value & Exchange-value \\
\hline Conserved Environment & 119 & 157 & 324 & 162.5 & 0.0 & 162.5 \\
Old-growth forest & 119 & 157 & 324 & 162.5 & 0.0 & 162.5 \\
Handicraft manufacture & 108 & 116 & 100 & 107.4 & 0.0 & 107.4 \\
Research assistants & 0 & 0 & 135 & 28.4 & 0.0 & 28.4 \\
Tourist guides & 0 & 24 & 48 & 13.9 & 0.0 & 13.9 \\
Entrance-fee collectors & 11 & 17 & 33 & 11.1 & 0.0 & 11.1 \\
Reserve custodian & 0 & 0 & 8 & 1.7 & 0.0 & 1.7 \\
\hline
\end{tabular}

$\mathrm{AO}=$ Agriculture oriented; $\mathrm{M}=$ Mixed; $\mathrm{SO}=$ Service oriented; OMYK=Otoch Ma'ax Yetel Kooh NPA

in decision making (Ewell 1984). Mainly because they were decontextualized from the cultural, productive, and ecological context of the region, within a few years, most of these development experiments generally fail (Ewell 1984, PeñaChapa et al. 2000, Jiménez-Osornio et al. 2003, Klepeis 2003).

After these repeated failures, federal and regional policy makers are now attempting to consolidate a new regional economic base founded on tourism, with an ecotourism focus for the "low productivity" rural sector. Development planners now target the CET as the primary productive Environment, using the argument that "low-impact" activities contribute to household cash income, meaning that everything that was either "inefficiently produced" (maize, beans, etc.) or "unsustainably gathered" (firewood, fish, game, water, etc.) can now be purchased. This interpretation is based on the stigmatization that government officials have placed on traditional agriculture. For instance, Mathews (2005) describes how Mexican government officials, in order to modernize the agricultural sector, have often depicted agricultural and pastoral fire users as irrational and ignorant, and blamed them for the actual deforestation and forest destruction. Following this rationale, planners presumably believe that monetary revenues from tourism can guarantee household access to most basic goods without pressuring natural resources. If effective, this rationale will probably accelerate dependency and displacement of traditional practices and disarticulation of local natural resources management institutions. This situation has already been documented. Martínez-Ballesté et al. (2006) found that the rapid expansion of the tourist industry and the trend for younger generations to abandon agriculture have led to an increasingly widespread loss of the traditional knowledge of Yucatec Maya sabal palm management. The crux of the problem with this new "environmentally friendly" regional development approach is that it is driven by a rationale focused on fragments of the system, in the apparent belief that traditional Yucatec Maya productive and extractive activities are harmful to the local environment and should be replaced by more "sustainable" practices. This interpretation responds to a short-term perspective in which apparently destructive practices (for instance, forest clearing and burning to open milpa plots or subsistence hunting) are not seen as elements of a larger, balanced system, and one that assumes tourism is non-destructive.

Although our conceptual framework highlights that treating the three Environments (Transformed, Used and Conserved) conjointly provides a clearer 
picture of multiple-use strategies in OMYK and illustrates why household appropriation of nature must be analyzed in an integrated way rather than in fragments (Alcorn 1989, Toledo et al. 2003), our findings suggest that the shift in OMYK household productive strategies from a primary sector (TET and UET) focus to a tertiary or service-sector focus (CET), could lead to a shortening of fallow periods. Vegetation felled by "agriculture-oriented" households was, on average, 18 years old, whereas that felled by those households with a "service-oriented" strategy was on average only 5 years old. The shortening of the fallow period could negatively affect OMYK household livelihoods in at least two ways: First, the ecological regeneration process that occurs in the UET as milpa plots are left fallow is extremely valuable for households because it creates the conditions required for replenishing soil fertility, which in turn allows future reimplementation of milpa land-use units in the TET and prevents the decline of crop yields. Second, the availability of some noncrop resources diminishes with shorter fallow periods. In this sense, the reduction in the availability of firewood is most important because all OMYK households depend on firewood to meet their fuel needs.

It is unlikely that milpa agriculture will completely disappear from the NPA. Although all households are willing to reduce milpa agriculture in order to increase ecotourism activities, most are not inclined to abandon this activity (see Table 1). In part, this could be because the main milpa crop, maize, is still regarded as sacred, and because maize and the milpa system itself are integral elements of the Yucatec Maya identity. Even those households that mainly work in ecotourism and that are well-off, monetarily speaking, can hire external labor to work their milpas. But, as has already been documented (Dalle and Blois 2006), a reduction in the area of farmed land could be accompanied by the clearing of younger successional stages closer to households. Interview data suggest that service-oriented households tended to choose new milpa plots based on ease of access and the presence of younger, more easily cleared, vegetation.

Oddly, the weakening of the multiple-use strategy in OMYK households has arisen from this system's very strength: its capacity to incorporate new activities into the resource management strategy in a potentially balanced way. Implementation of ecotourism activities and the lack of local institutions for regulating them initially caused social disruption among inhabitants. After many years, this was partially remedied by the creation and promotion of a local agreement regulating ecotourism activities, and then more expressly (although not definitively) addressed by the formation of an ecotourism management cooperative. The conflict and mistrust that this shift engendered among inhabitants has not completely dissipated, but the cooperative may now serve as the foundation of a new local institutional arrangement to guarantee equity among households and broader participation in decision making. Now that these ecotourism agreements and institutions are consolidating, however, the potential revenuegenerating ability of this activity threatens to displace other activities. The facility with which cash-income activities can penetrate traditional systems like that in OMYK can threaten the balance of a system that combines management of several land-use units to produce subsistence and market commodities, a situation that should not be underestimated. Therefore, as important as amplifying the range of available options is the way that activities are conceived and implemented in the whole strategy of natural resources management.

Our analysis demonstrates how households allocated a significant proportion $(41 \%)$ of their total labor to milpa agriculture and homegardening. These two activities constitute the two most important components of OMYK households' energy and food security strategy. They do not, in and of themselves, guarantee food security, but the fact that they are focused primarily on local energy and food needs makes them a valuable element of social security within the OMYK. As a matter of fact, this form of production and nature appropriation has effectively ensured household survival in the absence or sickness of members, or in response to catastrophic natural events such as hurricanes, forest fires, or droughts. This is no minor feat. For instance, during our visits to the area we observed that this social security system helped the communities to cope with the damages caused by hurricanes Emily and Wilma in 2005. Both hurricanes damaged harvests, bee colonies, and homegardens, and drastically decreased tourist visits, nevertheless, households took advantage of all the fallen organic material (trees and branches) to substantially increase charcoal production. The increase in charcoal production not only helped households to compensate for their economic losses, but also functioned as a risk reduction mechanism for uncontrolled fires that usually emerge after severe hurricanes. 
In addition to their energy and food security strategy, milpa agriculture and homegardening have played crucial roles in biodiversity conservation functions. The domestication of plants and animals by the ancient and modern Yucatec Maya affect forest vegetation composition (Gómez-Pompa and Kaus 1999) and help maintain and possibly even increase regional biodiversity (Gómez-Pompa and Bainbridge 1995, Faust 2001). Yucatec Maya agroforestry techniques promote the growth of shade-intolerant plants and provide quality forage for many wild animal species (Faust 2001). Use of milpa agriculture in OMYK has created a variety of landscape mosaics in areas that originally would have been covered by a single vegetation type. This represents a human-induced mechanism that theoretically maintains and even increases biodiversity. Indeed, spider monkey research in the area (Ramos-Fernández and Ayala-Orozco 2003, Ramos-Fernández et al. 2004) has shown that, although spider monkeys require large areas of oldgrowth forest with high tree diversity, they use practically all existing successional stages within this anthropogenic landscape mosaic.

\section{CONCLUSIONS}

The medium-term success of local natural resource management strategies on the Yucatan Peninsula highlights the importance of local populations' management knowledge to facing biodiversity threats in this region. The OMYK case highlights the complexity of contemporary Yucatec Maya natural resource management strategies. The inhabitants of the three studied communities still implement a diversified forest management system that maintains many of their traditional activities and techniques, while constantly adapting to social, economic, and ecological changes. These adaptations have often been achieved without compromising the primary objective of diversifying available livelihood options in the present and future. However, incorporation of some alternative economic activities, like ecotourism, and their intensification through the support of government programs are threatening some of these options.

Based on our research and years of experience working in the area, we do not oppose ecotourism per se. In fact, as this research has shown, this activity allows households from this region, and probably from many rural villages all around the world, to obtain a significant proportion of their monetary income for satisfying many of their needs.
The issue, however, is the risks associated with adopting a strategy based on productive specialization. In these Yucatec Maya communities, specialization not only poses serious risks to the partial control over food security and subsistence that the traditional strategy provides, but increases dependency on external agents, such as the tourist industry. As rural communities in the developing world rarely equate benefits with simple monetary rewards (Berkes 2004), public policies should foster the Yucatec Maya diversified system of production (including alternative economic activities), which has proven to be effective and flexible enough for managing the biodiversity of an area that is and has been constantly changing.

Responses to this article can be read online at: http://www.ecologyandsociety.org/voll3/iss2/art31/responses/

\section{Acknowledgments:}

Sincere thanks to Pronatura Península de Yucatán, Celene Espadas Manrique from Centro de Investigación Científica de Yucatán (CICY), and all the people from Punta Laguna, Yodzonot, and Campamento Hidalgo who generously offered help, support, and valuable insights. We really appreciate the challenging critique of the three anonymous reviewers. Financial support was received from the Consejo Nacional de Ciencia y Tecnología-México (Ph.D. scholarship to EGF) and from the Universidad Nacional Autónoma de México (Postdoctoral Fellowship to EGF).

\section{LITERATURE CITED}

Alcorn, J. B. 1989. An economic analysis of Huastec Mayan forest management. Pages 182-206 in J. G. Browder, editor. Fragile lands of Latin America: strategies for sustainable development. Westview Press, Boulder, Colorado, USA.

Barrera-Bassols, N., and V. M. Toledo. 2005. Ethnoecology of the Yucatec Maya: symbolism, knowledge and management of natural resources. Journal of Latin American Geography 4:9-41.

Batllori, E., F. Dickinson, A. García, M. Martín, I. González, M. Villasuso, and J. L. Febles. 2000. Socioecological regions of the Yucatán Peninsula. 
Pages 33-53 in W. Lutz, L. Prieto, and W. C. Sanderson, editors. Population, development, and environment on the Yucatan Peninsula: from ancient Maya to 2030. International Institute for Applied Systems Analysis, Vienna, Austria.

Berkes, F. 2004. Rethinking community-based conservation. Conservation Biology 18(3):621630 .

Berkes, F., and C. Folke. 1998. Linking social and ecological systems for resilience and sustainability. Pages 1-25 in F. Berkes and C. Folke, editors, Linking social and ecological systems. Management practices and social mechanisms for building resilience. Cambridge University Press, Cambridge, UK.

Caballero, J. 1992. Maya homegardens: past, present and future. Etnoecológica 1(1). [online] URL: http://www.etnoecologica.org.mx/Etnoecolo gica vol1 $\mathrm{n} 1 /$ articulos.htm.

Challenger, A. 1998. Utilización y conservación de los ecosistemas terrestres de México: pasado, presente y futuro. Comisión Nacional para el Conocimiento y Uso de la Biodiversidad, México D.F.

Comisión Nacional de Áreas Naturales Protegidas (CONANP). 2006. Programa de conservación y manejo, Área de Protección de Flora y Fauna Otoch Ma'ax Yetel Kooh, México. CONANP, Mexico D.F.

Dalle, S. P., and S. de Blois. 2006. Shorter fallow cycles affect the availability of noncrop plant resources in a shifting cultivation system. Ecology and Society 11(2): 2. [online] URL: http://www.eco logyandsociety.org/vol11/iss2/art2/.

Daltabuit, M., and O. Pi-Sunyer. 1990. Tourism development in Quintana Roo, Mexico. Cultural Survival 14:9-13.

Eastmond, A., and M. L. Robert. 2000. Henequen and the challenge of sustainable development in Yucatan, Mexico. Biotechnology and Development Monitor 41:11-15.

Estrada, A., and R. Coates-Estrada. 1988. Tropical rain forest conversion and perspectives in the conservation of wild primates (Alouatta and Ateles) in Mexico. American Journal of Primatology 14:315-327.
Ewell, P. T. 1984. Intensification of peasant agriculture in Yucatán. Cornell University, International Agricultural Economics Study, Ithaca, New York.

Faust, B. 1998. Mexican rural development and the plumed serpent: technology and Maya cosmology in the tropical forest of Campeche, Mexico. Greenwood Publishing Group, Wesport, Connecticut, USA.

Faust, B. 2001. Maya environmental successes and failures in the Yucatan Peninsula. Environmental Science and Policy 4:153-169.

Fischer-Kowalski, M., and H. Haberl. 1998. Sustainable development: socioeconomic metabolism and colonization of nature. International Social Science Journal 158:573-587.

Folan, W. J., B. B. Faust, W. Lutz, and J. D. Gunn. 2000. Social and environmental factors in the classic Maya collapse. Pages 2-32 in W. Lutz, L. Prieto, and W. C. Sanderson, editors. Population, development, and environment on the Yucatan Peninsula: from ancient Maya to 2030. International Institute for Applied Systems Analysis, Vienna, Austria.

García-Frapolli, E., B. Ayala-Orozco, M. Bonilla-Moheno, C. Espadas-Manrique, and G. Ramos-Fernández. 2007. Biodiversity conservation, traditional agriculture and ecotourism: land cover/ land use change projections for a natural protected area in the northeastern Yucatan Peninsula, Mexico. Landscape and Urban Planning 83:137-153.

Gómez-Pompa, A. 1987. On Maya silviculure. Mexican Studies/Estudios Mexicanos III:1-17.

Gómez-Pompa, A. 2003. Research challenges for the lowland Maya area: an introduction. In A. Gómez-Pompa, M. F. Allen, S. L. Fedick, and J J. Jiménez-Osornio, editors. The lowland Maya area. Three millennia at the human-wildland interface. Food Products Press, New York, New York, USA.

Gómez-Pompa, A., and D. A. Bainbridge. 1995. Tropical forestry as if people mattered. Pages 408 422 in A. Lugo and C. Lowe, editors. Tropical forests: management and ecology. Springer-Verlag, New York, New York, USA.

Gómez-Pompa, A., and A. Kaus. 1999. From pre- 
Hispanic to future conservationist alternatives: lessons from Mexico. Proceedings of the National Academy of Science USA 96:5982-5986.

Harrison, P. D., and B. L. Turner. 1978. PreHispanic Maya agriculture. University of New Mexico Press, Albuquerque, New Mexico, USA.

Hostettler, U. 1996. Milpa agriculture and economic diversification. Socioeconomic change in a Maya peasant society of central Quintana Roo, 1900-1990s. Dissertation, University of Berne, Switzerland.

Jiménez Osornio, J. J., A. Caballero, D. Quezada, and E. Bello Baltazar. 2003. Estrategias tradicionales de apropriación de los recursos naturales. Pages 189-200 in P. ColungaGarcíaMarín and A. Larque Saavedra, editors. Naturaleza y sociedad en el área maya. Pasado, presente y futuro. Academia Mexicana de Ciencias y Centro de Investigaciones Científicas de Yucatán, México D.F.

Juárez,A. M. 2002. Ecological degradation, global tourism, and inequality: Maya interpretations of the changing environment in Quintana Roo, Mexico. Human Organization 61:113-124.

Klepeis, P. 2003. Development policies and tropical deforestation in the southern Yucatán Peninsula: centralized and decentralized approaches. Land Degradation and Development 14:541-561.

Lutz, W., L. Prieto, and W. Sanderson, editors. 2000. Population, development, and environment on the Yucatan Peninsula: from ancient Maya to 2030. International Institute for Applied Systems Analysis, Vienna, Austria.

Martínez-Ballesté, A., C. Martorell, and J. Caballero. 2006. Cultural or ecological sustainability? The effect of cultural change on sabal palm management among the lowland Maya of Mexico. Ecology and Society 11(2): 27. [online] URL: http: //www.ecologyandsociety.org/vol11/iss2/art27/.

Mathews, A. S. 2005. Power/knowledge, power/ ignorance: forest fires and the state in Mexico. Human Ecology 33(6):795-820.

Mowforth, M., and I. Munt. 1998. Tourism and sustainability: new tourism in the third world. Routledge, London, UK.
Nations, J. D., R. B. Primack, and D. Bray. 1998. Introduction: the Maya forest. Pages xiii-xx in R. B. Primack, D. B. Bray, H. A. Galletti, and I. Ponciano, editors. Timber, tourists, and temples: conservation and development in the Maya forest of Belize, Guatemala, and Mexico. Island Press, Washington, D.C., USA.

Peña Chapa, J. L., M. Martin Castillo, and J. C. Gonzalez Avila. 2000. The performance of the economy of the Yucatán Peninsula from 1970 1993. Pages 108-119 in W. Lutz, L. Prieto, and W. C. Sanderson, editors. Population, development, and environment on the Yucatan Peninsula: from ancient Maya to 2030. International Institute for Applied Systems Analysis, Vienna, Austria.

Ramírez-Barajas, P. J., N. Torrescano-Valle, A. Tecpa-Jiménez, and J. Vázquez-Rodríguez. 2001. Importancia y uso del entorno natural en una comunidad indígena maya (Petcacab, Quintana Roo, México). Revista Especializada en Ciencias Químico-Biológicas 4:61-71.

Ramos-Fernández, G., and B. Ayala-Orozco. 2003. Population size and habitat use of spider monkeys in Punta Laguna, Mexico. Pages 191-209 in L. K. Marsh, editor, Primates in fragments: ecology and conservation. Klewer/Plenum Press, New York, New York, USA.

Ramos-Fernández, G., L. G. Vick, F. Aureli, C. Schaffner, and D. M. Taub. 2004. Use of secondary vegetation by spider monkeys (Ateles geoffroyi). Folia Primatologica 75Suppl 1-2:406.

Re Cruz, A. 2003. Milpa as an ideological weapon: tourism and Maya migration to Cancún. Ethnohistory 50(3):489-502.

Redfield, R., and Villa Rojas, A. 1934. Chan Kom: a Maya village. Waveland Press, Long Grove, Illinois, USA.

Secretaría de Turismo (SECTUR). 2005. Estadísticas del sector. Secretaría de Turismo. [online] URL: http://datatur.sectur.gob.mx/jsp/index. jsp.

Taylor, J. E., and I. Adelman. 1996. Village economies: the design, estimation, and use of village wide economic models. Cambridge University Press, New York, New York, USA. 
Toledo, V. M. 2008. Metabolismos rurales: hacia una teoría económico-ecológica de la apropiación de la naturaleza. Revista Iberoamericana de Economía Ecológica 7. [online] URL: http://www. redibec.org/.

Toledo, V. M., P. Alarcón-Chaires, P. Moguel, M. Olivo, A. Cabrera, E. Leyequien, and A. Rodríguez-Aldabe. 2001. El atlas etnoecológico de México y Centroamérica: fundamentos, métodos y resultados. Etnoecológica 6:7-41. [online] URL: http://www.etnoecologica.org.mx/Etnoecologica vol6 n3/ art toledo.htm.

Toledo, V. M., N. Barrera-Bassols, E. GarcíaFrapolli, and P. Alarcón-Chaires. 2008. Uso multiple y biodiversidad entre los mayas yucatecos (México). Interciencia 33(5):345-352.

Toledo, V. M., B. Ortiz, and S. Medellín-Morales. 1994. Biodiversity islands in a sea of pasturelands: indigenous resource management in the humid tropics of Mexico. Etnoecológica 2(3). [online] URL: http://www.etnoecologica.org.mx/Etnoecolo gica vol2 n3/art toledo.htm.

Toledo, V. M., B. Ortiz-Espejel, L. Cortés, P. Moguel, and M. J. Ordoñez. 2003. The multiple use of tropical forests by indigenous peoples in Mexico: a case of adaptive management. Conservation Ecology 7(3). [online] URL: http://w ww.ecologyandsociety.org/vol7/iss3/art9/.

Torres, R. 2003. Linkages between tourism and agriculture in Mexico. Annals of Tourism Research 30:546-566.

World Travel and Tourism Council (WTTC). 2008. Tourism satellite accounting. The 2008 travel and tourism economic research: executive summary. WTTC, London, UK.

Wunder, S. 2000. Ecotourism and economic incentives-an empirical approach. Ecological Economics 32:465-479. 